Original Contribution

\title{
EFFECT OF PARTIAL REPLACEMENT OF WHEAT WITH EXTRUDED BAKERY WASTE IN FATTENED DOMESTIC QUAIL RATIONS
}

\author{
H. Lukanov ${ }^{1}$, I. Pavlova ${ }^{2}$, A. Genchev ${ }^{1}$ \\ ${ }^{1}$ Department of Animal Science - Monogastric and Other Animals, Faculty of Agriculture, \\ Trakia University, Stara Zagora, Bulgaria. \\ ${ }^{2}$ Department of General Livestock Breeding, Faculty of Veterinary Medicine, Trakia University, \\ Stara Zagora, Bulgaria.
}

\begin{abstract}
A study was conducted to establish the possibilities for replacing 5 and $10 \%$ of wheat in the combined feed for domestic quails with extruded bakery waste and to study its impact on the growth and productivity of quails. 270 domestic quails from the specialized meat production line WG were included in the experiment and divided according to the principle of analogues into 3 aligned groups: control, fed with mixtures without the inclusion of extruded waste from bakeries; experimental I, in the mixtures of which $5 \%$ of the wheat was replaced with extruded bakery waste and experimental II, in which $10 \%$ of the wheat in the mixtures was replaced by extruded bakery waste. The experiment continued until the age of 35 days. The following signs were monitored: mortality (\%), live weight (g), average daily weight gain $(\mathrm{g})$, feed consumption $(\mathrm{g})$, feed conversion $(\mathrm{kg} / \mathrm{kg}$ weight gain). The study showed that for the 35-day period, the quails from the specialized meat production line WG consumed an average of 812-817 $\mathrm{g}$ of compound feed, with an average increase of the weight gain 255-258 $\mathrm{g}$. Under these conditions, the average feed conversion ratio is in the range of 3.15-3.20. In the course of the trial it was found that the replacement of 5 and $10 \%$ of wheat in the feed mixture with extruded bakery waste reduces the value of compound feed by an average of 0.85 and $1.7 \%$, but does not affect the studied productivity traits and economic indicators from fattening. When summarizing the results for the 35-day period, the differences between the control and experimental groups on the studied productive traits are less than $2 \%$, and the difference in the value of $1 \mathrm{~kg}$ weight gain between the groups is less than $1 \%$.
\end{abstract}

Key words: Quail fattening, WG line, Growth, Body weight gain, FCR.

\section{INTRODUCTION}

One of the global problems facing modern humanity is the sufficient, quantity and quality nutrition of people, not only in developing countries but also in those with a medium and high standard of living. At the beginning of the XXI century, there were still regions in the world where people were severely deficient in protein and energy for the proper functioning of the body. According to FAO reports, the number of malnourished people in these countries increased from 824 million in the 1990 s to 870 million in the first 10 years of the new century (1). One way to solve this

\footnotetext{
*Correspondence to: Hristo Lukanov, Department of Animal Science - monogastric and other animals, Faculty of Agriculture, Trakia University, Stara Zagora,Bulgaria,drlukanov@gmail.com
}

problem is in the development of poultry farming as an industry that can quickly and environmentally produce at an affordable price a sufficient amount of complete animal protein to feed the human population (2).

On the other side, the other global problem sounds almost criminal - the loss of food that humanity generates every year. FAO experts estimate that they make up almost 1.3 billion tonnes, including fresh fruit and vegetables, meat, bakery products, dairy products and more (3). Trying to even partially overcome this problem has the potential to increase incomes and improve the living standards of a huge number of people in poor countries. Statistics show that approximately $1 / 3$ of the world's food production does not reach the human table, and the main losses in countries 


\section{LUKANOV H., et al.}

with high and medium living standards are formed in the consumer phase when all the costs of production, logistics and even commercial supply have already been incurred (4). In North America and Europe, these food losses, most of which are still fit for human consumption, are estimated at approximately 95-115 kg per capita per year. This justifies Parfitt et al. (2010) to classify them as 'food waste', which according to the authors is related to the way of thinking and wasteful behavior of traders and consumers in these parts of the world (5).

For sub-Saharan Africa, South and South-East Asia, food losses are formed during the production and processing phases and are estimated at around 6-11 $\mathrm{kg}$ per person per year (4), which compared to the population of these regions, is not small at all.

Cereals are of the greatest importance worldwide, as they are the main raw material for feeding both humans and animals. Wheat is the most important cereal for the people of Europe and North America. Unfortunately, the food produced on its basis records the biggest losses - bread, a huge range of bakery products, pastry, etc. According to Gustavsson et al. (2011), these losses are formed at the consumer stage and account for approximately 40 to $50 \%$ of the total food losses formed in cereals (4).

The huge scale of food losses, based on the main cereal for human consumption - wheat, makes researchers look for opportunities to utilize them as feed. There are numerous publications in the world scientific literature proving the possibilities of replacing some of the cereal components of compound feeds (corn and wheat) with bakery or bakery waste. This is a possible option, especially for small farms that have the ability to produce compound feed on site. This can be a powerful lever for them to reduce the cost of feed and increase competitiveness.

As early as the 1960s, Damron et al. (1965) showed that dried bakery waste can be included up to $10 \%$ in a compound feed of broiler chickens without adversely affecting their growth and productivity (6). Subsequent studies by Al-Tulaihan et al. (2004) confirm these results (7). The authors characterize bakery waste as energy-rich, low in crude fiber and significantly lower in price, with recommendations to replace up to $30 \%$ of maize in compound feed for broilers. This conclusion is also confirmed by Yadav et al. (2014), as the author's team allows the replacement of up to $40 \%$ of corn with bakery waste (8). The studies of Kricka et al. (2019) showed that better productivity in broilers is obtained when up to $10 \%$ of maize is replaced in compound feed with extruded black bread waste compared to that of white bread (9). In a detailed analysis by balance experiments of the nutritional value and digestibility of nutrients of extruded bakery waste Penkov and Chobanova (2020) found that the most suitable substitute in poultry feed mixtures is wheat (10).

Summarizing the literature reference given so far, we can see that the waste from the bakery industry as a quantity is significant and there is a need to develop methods for their utilization as a feed component. Studies in this direction showed that bakery waste can replace between 10 and $40 \%$ of the energy grain components in compound feed for broilers. Taking these facts into account, we set ourselves the goal of exploring the possibilities of replacing 5 and $10 \%$ of wheat in compound feed for domestic quails with extruded bakery waste and to establish the impact of this substitution on quail growth and productivity.

\section{MATERIAL AND METHODS}

The study was conducted in the 'Poultry experimental base' of the Faculty of Agriculture, Trakia University, Stara Zagora, Bulgaria. 270 experimental quails from the specialized meatproducing line WG were included in the experimental production. At 1 day of age, the quails were randomly divided into 3 analog groups of 90, designated as control, I experimental and II experimental, respectively. In the control group, the grain component in the compound feed was represented by maize and wheat. In the experimental groups, part of the wheat was replaced by extruded bakery waste, respectively in the 1 st experimental group by $5 \%$, and in the 2nd experimental group - 10\%. During the experimental period, 3-phase feeding with starter, grower and finishing compound feed was applied (Table 1). The breeding conditions of the birds from the three groups were the same and strictly corresponded to the requirements of the species. The experiment continued until the age of 35 days. The following signs were monitored: mortality (\%), live weight (g), average daily weight gain $(\mathrm{g})$, feed consumption $(\mathrm{g})$, feed conversion ( $\mathrm{kg} / \mathrm{kg}$ weight gain). 
Table 1. Component and nutritional composition of the compound feed used

\begin{tabular}{|c|c|c|c|c|c|c|c|c|c|}
\hline & \multicolumn{3}{|c|}{ Control group } & \multicolumn{3}{|c|}{ I group } & \multicolumn{3}{|c|}{ II group } \\
\hline & Starter & Grower & Finisher & Starter & Grower & Finisher & Starter & Grower & Finisher \\
\hline & \multicolumn{9}{|c|}{ Feed components, $\%$} \\
\hline Corn & 29.2 & 35.5 & 38.8 & 29 & 35.1 & 38.65 & 28.8 & 35 & 38.4 \\
\hline Wheat & 21 & 23.8 & 27 & 16 & 19 & 22 & 11 & 13.9 & 17 \\
\hline Extruded & & & & & & & & & \\
\hline bakery waste & 0 & 0 & 0 & 5 & 5 & 5 & 10 & 10 & 10 \\
\hline $\begin{array}{l}\text { Soybean meal, } \\
44 \% \text { CP }\end{array}$ & 34.6 & 25.8 & 20 & 34.7 & 25.85 & 20 & 34.75 & 25.93 & 20.1 \\
\hline $\begin{array}{l}\text { Sunflower } \\
\text { meal, 34\% CP } \\
\text { Fish meal, }\end{array}$ & 8 & 8.5 & 9 & 8 & 8.5 & 9 & 8 & 8.5 & 9 \\
\hline $72 \% \mathrm{CP}$ & 2 & 1 & 0 & 2 & 1 & 0 & 2 & 1 & 0 \\
\hline $\begin{array}{l}\text { Sunflower oil } \\
\text { Dicalcium }\end{array}$ & 0.615 & 0.905 & 1 & 0.865 & 1.055 & 1.15 & 0.865 & 1.18 & 1.3 \\
\hline phosphate & 1.92 & 1.82 & 1.71 & 1.92 & 1.82 & 1.71 & 1.92 & 1.82 & 1.71 \\
\hline $\begin{array}{l}\text { Calcium } \\
\text { carbonate }\end{array}$ & 1.52 & 1.48 & 1.43 & 1.52 & 1.48 & 1.43 & 1.52 & 1.48 & 1.43 \\
\hline $\begin{array}{l}\text { Vitamin- } \\
\text { mineral premix }\end{array}$ & 0.6 & 0.6 & 0.5 & 0.6 & 0.6 & 0.5 & 0.6 & 0.6 & 0.5 \\
\hline $\mathrm{NaCl}$ & 0.2 & 0.2 & 0.2 & 0.2 & 0.2 & 0.2 & 0.2 & 0.2 & 0.2 \\
\hline $\mathrm{Na}_{2} \mathrm{CO}_{3}$ & 0.1 & 0.1 & 0.1 & 0.1 & 0.1 & 0.1 & 0.1 & 0.1 & 0.1 \\
\hline L-lysine, $98 \%$ & 0.11 & 0.175 & 0.15 & 0.11 & 0.175 & 0.15 & 0.11 & 0.17 & 0.15 \\
\hline $\begin{array}{l}\text { DL- } \\
\text { methionine, } \\
99 \%\end{array}$ & 0.135 & 0.12 & 0.11 & 0.135 & 0.12 & 0.11 & 0.135 & 0.12 & 0.11 \\
\hline & & & & $\mathrm{Nu}$ & itional co & position & & & \\
\hline $\mathrm{EPR}^{*}$ & 110.27 & 134.28 & 156.31 & 110.13 & 134.29 & 156.58 & 110.13 & 134.23 & 156.48 \\
\hline $\mathrm{ME}, \mathrm{MJ} / \mathrm{kg}$ & 11.06 & 11.51 & 11.79 & 11.05 & 11.51 & 11.79 & 11.05 & 11.50 & 11.79 \\
\hline $\mathrm{CP}, \%$ & 24.00 & 20.51 & 18.04 & 24.01 & 20.51 & 18.02 & 24.01 & 20.50 & 18.03 \\
\hline $\mathrm{CF}, \%$ & 5.28 & 5.02 & 4.90 & 5.23 & 4.99 & 4.87 & 5.23 & 4.97 & 4.85 \\
\hline $\mathrm{Ca}, \%$ & 1.20 & 1.10 & 1.00 & 1.20 & 1.10 & 1.00 & 1.20 & 1.10 & 1.00 \\
\hline Available P, \% & 0.50 & 0.45 & 0.40 & 0.50 & 0.45 & 0.40 & 0.50 & 0.45 & 0.40 \\
\hline Lysine, \% & 1.30 & 1.10 & 0.91 & 1.31 & 1.10 & 0.90 & 1.31 & 1.10 & 0.91 \\
\hline Methionine \% & 0.52 & 0.45 & 0.40 & 0.52 & 0.45 & 0.40 & 0.52 & 0.45 & 0.40 \\
\hline Cys+met, \% & 0.92 & 0.81 & 0.73 & 0.92 & 0.81 & 0.73 & 0.92 & 0.81 & 0.73 \\
\hline $\begin{array}{l}\text { Linoleic acid, } \\
\%\end{array}$ & 1.30 & 1.62 & 1.75 & 1.47 & 1.72 & 1.85 & 1.47 & 1.79 & 1.95 \\
\hline $\begin{array}{l}\text { Feed price, } \\
\text { EUR/t }\end{array}$ & 389.68 & 342.78 & 301.65 & 383.87 & 339.93 & 298.64 & 383.87 & 336.98 & 295.94 \\
\hline
\end{tabular}

*EPR - Energy-Protein Ratio

At 14 days of age, the birds were divided by sex, based on plumage color, and further control of traits was conducted by sex.

Health status and mortality were reported daily. Live weight was monitored weekly using a CB 2000 balance. At 1 and 7 days of age, the accuracy of live weight determination was up to $0.1 \mathrm{~g}$, and at $14,21,28$ and 35 days of age - up to $1 \mathrm{~g}$. The amount of feed fed and the residues of unconsumed feed from the previous day were determined daily with accuracy up to $1 \mathrm{~g}$. Feed intake was registered on a daily basis per group. Feed conversion ratio (FCR) was calculated on the basis of feed intake and weekly weight gain. Indices of production efficiency were calculated adopting those used in broiler industry - European Production Efficiency Factor (EPEF) and European Broiler Index (EBI), using the following equations (11):
$\mathrm{EPEF}=[($ viability, $\% \times$ body weight, $\mathrm{kg}) /($ age, days $\times$ FCR $)] \times 100($ Equation 1$)$

$\mathrm{EBI}=($ viability, $\% \times$ Average daily gain, $\mathrm{g}) /(\mathrm{FCR}$ $\times 10)($ Equation 2)

The statistical evaluation of the obtained results was done with the statistical package IBM $®$ SPSS $®$ Statistics (V26).

\section{RESULTS AND DISCUSSION}

During the experimental period, the survival of quails from the three groups was very high, which is an indicator of both the quality of the genetic material and the health and breeding conditions of the birds (Table 2). For the 35-days experimental period, the average survival was over $97 \%$ for all three groups, and no connection could be made for the influence of the tested factor on the commented 
feature. This conclusion corresponds to the published results of Kricka et al. (2019) in a similar research conducted with broiler chickens (9).

Table 2. Livability of quails of line $W G, \%$

\begin{tabular}{|c|c|c|c|}
\hline Age, days & Control group & I group & II group \\
\hline $1-7$ & 98.96 & 100 & 100 \\
\hline $8-14$ & 100 & 100 & 98.75 \\
\hline $15-21$ & 100 & 100 & 100 \\
\hline $22-28$ & 100 & 100 & 98.65 \\
\hline $29-35$ & 100 & 98.46 & 100 \\
\hline $1-35$ & 98.73 & 98.71 & 97.41 \\
\hline
\end{tabular}

The results for change of the live weight of the quails from the three groups, including by sex, after 14 days of age are presented in Table 3. Analyzing the dynamics of change in the live weight of quails, we are convinced that the highest growth rate is in the first week of the life of quails when the mass increases more than 4.5 times (Figure 1). The presented trend is described in the other authors' researches, as the differences were in the amount of the increase of the mass, which for the meatproducing populations is in the range from 2.3-2.7 times $(12,13)$ to $3.1-3.4$ times $(14$, 15). In another earlier and larger study, with birds of the same line, a 3.7-fold increase in mass was recorded (16). In our study, the replacement of wheat with $5 \%$ or $10 \%$ extruded waste from bakeries did not affect the growth rate and the change in live weight (Table 3, Figure 1). With the exception of the first week of the experiment, when the differences between the groups were in the range of $2.1-3.4 \%$, during the rest of the period they varied between 0.13 and $1.7 \%$. The differences depending on the sex of the birds were more noticeable, which became more and more pronounced after the age of 3 weeks. However, at 3 and 4 weeks of age, the size of the intergroup differences in growth intensity was in the range of $1.3-4.7 \%$. Statistically significant differences were reported in the groups where the mass of female birds exceeded that of males by more than $3.5 \%$ $(\mathrm{P}<0.05)$. Logically, given the sexual maturation and the more intensive development of the female reproductive system, at 5 weeks of age, the largest differences between the sexes were registered (3.9-12.1\%), and in all groups, they were statistically significant $(\mathrm{P}<0.05)$. The results obtained by us are expected, given the fact that they follow a biological pattern characteristic of quails as a species. However, the size of the sex differences is influenced both by the breed
/ linear affiliation and by the direction of the selection work carried out with the given genotype. In this case, the WG line is a specialized meat production line selected on the basis of growth intensity and precocity. This is the main reason for the higher growth rate during the first 2 weeks of life of quails of this line, which by 14 days of age increase their live weight from 8.9 (16) to 10.7 times, registered in the present study. This is also a prerequisite for the higher live weight at 5 weeks of age between the WG line and the results published by other authors for meattype quails, and the size of these differences can reach up to $45 \%$ (13).

The average daily weight gain of WG quails found in the present study was highest between the 2nd and 4th week, and the peak was between 15 and 21 days of age (Table 4). In an earlier study with the same population, with shorter control periods, it was found that the peak in the average daily weight gain of the WG line was between the 18th and 21st day (16). Our results correspond to those published by other authors, who present similar dynamics of change in the average daily weight gain in quail-type quails $(14,15)$. According to Naumova and Donets (2013), the average daily growth in the Pharaoh breed was highest between 21 and 40 days of age, and the peak values were reached between 30 and 40 days of age (12). Similar to live weight, the average daily gain is not significantly affected by the tested factor - the replacement of 5\% and $10 \%$ of wheat in the combined feed for fattened quail with extruded bakery waste. Up to 28 days of age, the growth values were slightly higher in the experimental groups, but the differences were in the range of $0.1-4.5 \%$ and were not statistically proven $(\mathrm{P}>0.05)$. Considering this feature depending on the sex of the birds, we saw that between 15 and 28 days of age the average daily growth in 
females was slightly higher than in males, but the differences were small and not statistically significant $(\mathrm{P}>0.05)$. Nevertheless, in total for the period from 1 to 28 days of age, the male quails achieved a total growth between 220 and $223 \mathrm{~g}$, and the female - 226-229 g. In both sexes the differences between the groups are less than $1 \%$ and are statistically insignificant $(\mathrm{P}>0.05)$.

Table 3. Average body weight, $g$

\begin{tabular}{|c|c|c|c|c|c|c|}
\hline \multirow{2}{*}{$\begin{array}{l}\text { Age, } \\
\text { days }\end{array}$} & \multicolumn{2}{|c|}{ Control group } & \multicolumn{2}{|c|}{ I group } & \multicolumn{2}{|c|}{ II group } \\
\hline & $\hat{0}$ & $q$ & $\hat{0}$ & o & $\hat{o}$ & q \\
\hline 1 & \multicolumn{2}{|c|}{$10.4 \pm 0.08$} & \multicolumn{2}{|c|}{$10.5 \pm 0.08$} & \multicolumn{2}{|c|}{$10.5 \pm 0.08$} \\
\hline $\min \div \max$ & \multicolumn{2}{|c|}{$9.2 \div 12.0$} & \multicolumn{2}{|c|}{$9.2 \div 12.1$} & \multicolumn{2}{|c|}{$9.2 \div 12.1$} \\
\hline 7 & \multicolumn{2}{|c|}{$48.2 \pm 0.56$} & \multicolumn{2}{|c|}{$49.8 \pm 0.63$} & \multicolumn{2}{|c|}{$49.2 \pm 0.58$} \\
\hline $\min \div \max$ & \multicolumn{2}{|c|}{$35.8 \div 58.7$} & \multicolumn{2}{|c|}{$37.5 \div 62.2$} & \multicolumn{2}{|c|}{$34.7 \div 60.0$} \\
\hline & \multicolumn{2}{|c|}{$112.1 \pm 0.97$} & \multicolumn{2}{|c|}{$114.0 \pm 1.17$} & \multicolumn{2}{|c|}{$113.4 \pm 1.05$} \\
\hline 14 & $111.6 \pm 1.21$ & $112.6 \pm 1.53$ & $112.4 \pm 1.66$ & $115.7 \pm 1.65$ & $112.5 \pm 1.26$ & $114.6 \pm 1.78$ \\
\hline $\min \div \max$ & $100.0 \div 138.0$ & $86.0 \div 130.0$ & $86.0 \div 130.0$ & $90.0 \div 137.0$ & $91.0 \div 129.0$ & $93.0 \div 138.0$ \\
\hline & \multicolumn{2}{|c|}{$182.1 \pm 1.46$} & \multicolumn{2}{|c|}{$182.3 \pm 1.71$} & \multicolumn{2}{|c|}{$179.6 \pm 1.45$} \\
\hline 21 & $180.2 \pm 1.93$ & $183.8 \pm 2.20$ & $178.17 \pm 2.33$ & $186.67 \pm 2.36^{*}$ & $176.84 \pm 1.64$ & $182.97 \pm 2.47 *$ \\
\hline \multirow[t]{2}{*}{$\min \div \max$} & $158.0 \div 221.0$ & $152.0 \div 208.0$ & $150.0 \div 207.0$ & $160.0 \div 219.0$ & $152.0 \div 207.0$ & $160.0 \div 216.0$ \\
\hline & \multicolumn{2}{|c|}{$235.4 \pm 1.71$} & \multicolumn{2}{|c|}{$234.9 \pm 1.97$} & \multicolumn{2}{|c|}{$235.1 \pm 1.90$} \\
\hline 28 & $232.2 \pm 2.17$ & $238.8 \pm 2.61$ & $230.4 \pm 2.83 *$ & $239.8 \pm 2.57$ & $233.6 \pm 2.33$ & $236.7 \pm 3.11$ \\
\hline \multirow[t]{2}{*}{$\min \div \max$} & $202.0 \div 258.0$ & $202.0 \div 265.0$ & $196.0 \div 269.0$ & $212.0 \div 273.0$ & $207.0 \div 278.0$ & $199.0 \div 269.0$ \\
\hline & \multicolumn{2}{|c|}{$269.3 \pm 3.37$} & \multicolumn{2}{|c|}{$267.3 \pm 2.70$} & \multicolumn{2}{|c|}{$271.6 \pm 2.46$} \\
\hline 35 & $255.2 \pm 4.53$ & $286.1 \pm 3.0 * * *$ & $257.9 \pm 3.60$ & $279.4 \pm 2.8 * * *$ & $266.6 \pm 3.01$ & $277.0 \pm 3.83 *$ \\
\hline $\min \div \max$ & $194.0 \div 299.0$ & $255.0 \div 313.0$ & $215.0 \div 300.0$ & $246.0 \div 315.0$ & $234.0 \div 315.0$ & $243.0 \div 320.0$ \\
\hline
\end{tabular}

Note: Differences between the live weight of male and female birds of the same group are noted with *: $*-\mathrm{P}<0.05$; ** $-\mathrm{P}<0.01$, and $* * *-\mathrm{P}<0.001$.

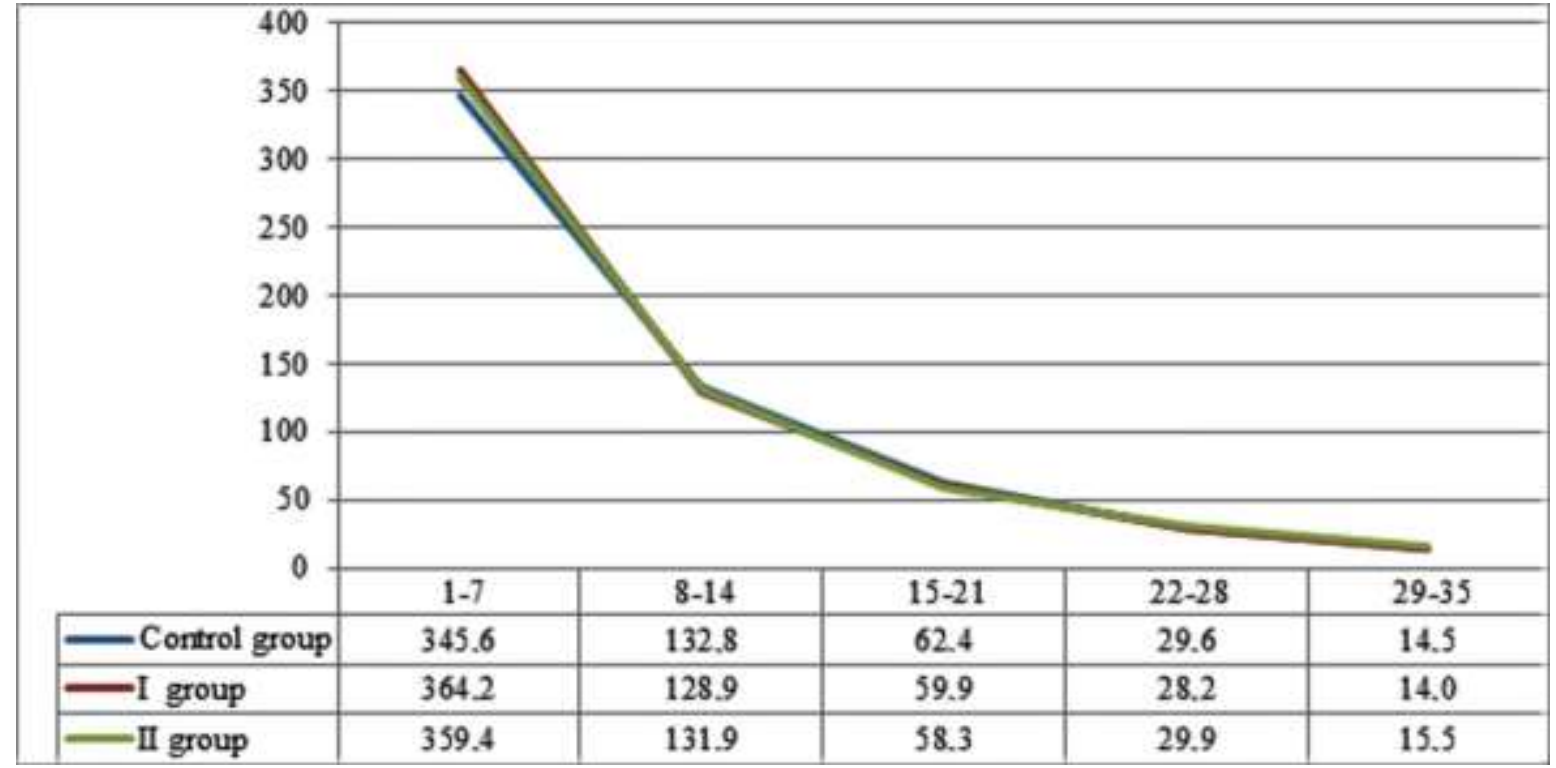

Figure 1. Growth intensity, $\%$

During the final stage of the experiment (29-35 days), the average daily weight gain significantly decreased (between 50 and $60 \%$ on average), and the changes in males were more drastic. This is due to the fact that during this period the birds began to enter the phase of sexual maturation, during which changes in their behavior occurred. This is the period when the males, depending on their individual development, are often over-excited and show aggression towards the other males in the group. These changes deepen with age, increasing the incidence of trauma and splitting of the eyes and scalp. Birds are often hyperactive and greatly reduce feed consumption. They form a small weight gain, and some of them even lose weight. Confirmation of this can be found in other studies with this species of poultry (15-17). This is the main reason why during the period of 29-35 days of age the average daily growth of male quails decreased to 3.3-4.7 $\mathrm{g}$. This 
represents a decrease between 1.7 and 2.3 times compared to the previous period, and the control group was most affected. A probable explanation for this fact can be sought in the individual characteristics of some of the males in the control group, in which there was intensive development of secondary sexual characteristics leading to early sex-related behavioral changes. During the same period, female birds still remained calm, actively consumed feed and although their growth decreased between 15 and 32\%, they formed an average daily growth of about 5.7-6.7 g. As a result, the difference between male and female birds increased and, with the exception of experimental group II, it was statistically proven $(\mathrm{P}<0.01)$. Summarizing the results of the experiment, we found that the total increase for the period 1-35 days varied between 183.5 and $289.5 \mathrm{~g}$ for males and between 232.5 and $303.5 \mathrm{~g}$ for females. The difference between the average values of weight gain in male and female quails was the lowest (4\%) in the birds of experimental group II and the highest $(12.6 \%)$ in the control group, and in all groups it is highly significant $(\mathrm{P}<0.001)$.

Table 4. Average daily weight gain, $g$

\begin{tabular}{|c|c|c|c|c|c|c|}
\hline \multirow{2}{*}{$\begin{array}{l}\text { Age } \\
\text { period, } \\
\text { days }\end{array}$} & \multicolumn{2}{|c|}{ Control group } & \multicolumn{2}{|c|}{ I group } & \multicolumn{2}{|c|}{ II group } \\
\hline & $\hat{0}$ & q & $\hat{\sigma}$ & q & $\hat{o}$ & 운 \\
\hline $1-7$ & \multicolumn{2}{|c|}{$5.39 \pm 0.08$} & \multicolumn{2}{|c|}{$5.62 \pm 0.09$} & \multicolumn{2}{|c|}{$5.53 \pm 0.08$} \\
\hline $\min \div \max$ & \multicolumn{2}{|c|}{$3.62 \div 6.89$} & \multicolumn{2}{|c|}{$3.86 \div 7.39$} & \multicolumn{2}{|c|}{$3.46 \div 7.07$} \\
\hline $8-14$ & \multicolumn{2}{|c|}{$9.14 \pm 0.14$} & \multicolumn{2}{|c|}{$9.17 \pm 0.17$} & \multicolumn{2}{|c|}{$9.18 \pm 0.15$} \\
\hline $\min \div \max$ & \multicolumn{2}{|c|}{$5.41 \div 12.83$} & \multicolumn{2}{|c|}{$5.17 \div 12.46$} & \multicolumn{2}{|c|}{$5.98 \div 12.69$} \\
\hline $15-21$ & \multicolumn{2}{|c|}{$9.92 \pm 0.20$} & \multicolumn{2}{|c|}{$9.93 \pm 0.22$} & \multicolumn{2}{|c|}{$9.68 \pm 0.20$} \\
\hline \multirow[t]{2}{*}{$\min \div \max$} & $9.61 \pm 0.22$ & $10.25 \pm 0.33$ & $9.63 \pm 0.31$ & $10.26 \pm 0.32$ & $9.52 \pm 0.21$ & $9.85 \pm 0.35$ \\
\hline & $6.62 \div 12.34$ & $5.63 \div 13.63$ & $5.80 \div 13.52$ & $7.04 \div 14.33$ & $7.36 \div 13.50$ & $6.48 \div 14.48$ \\
\hline $22-28$ & \multicolumn{2}{|c|}{$7.69 \pm 0.24$} & \multicolumn{2}{|c|}{$7.34 \pm 0.27$} & \multicolumn{2}{|c|}{$7.69 \pm 0.27$} \\
\hline \multirow[t]{2}{*}{$\min \div \max$} & $7.61 \pm 0.31$ & $7.78 \pm 0.37$ & $7.23 \pm 0.41$ & $7.46 \pm 0.37$ & $7.79 \pm 0.33$ & $7.60 \pm 0.44$ \\
\hline & $3.30 \div 11.30$ & $2.35 \div 11.53$ & $2.32 \div 12.75$ & $3.50 \div 12.21$ & $3.98 \div 14.12$ & $2.20 \div 12.20$ \\
\hline $29-35$ & \multicolumn{2}{|c|}{$4.87 \pm 0.45$} & \multicolumn{2}{|c|}{$4.69 \pm 0.35$} & \multicolumn{2}{|c|}{$5.21 \pm 0.35$} \\
\hline \multirow[t]{2}{*}{$\min \div \max$} & $3.30 \pm 0.65$ & $6.74 \pm 0.43 * * *$ & $3.93 \pm 0.52$ & $5.67 \pm 0.40 * *$ & $4.70 \pm 0.43$ & $5.76 \pm 0.55$ \\
\hline & $-8.45 \div 9.55$ & $2.29 \div 10.58$ & $-2.19 \div 9.95$ & $0.91 \div 10.76$ & $0.05 \div 11.62$ & $0.90 \div 11.90$ \\
\hline $1-35$ & \multicolumn{2}{|c|}{$258.87 \pm 3.37$} & \multicolumn{2}{|c|}{$256.79 \pm 2.70$} & \multicolumn{2}{|c|}{$261.06 \pm 2.46$} \\
\hline $\min \div \max$ & $244.8 \pm 4.53 a$ & $275.7 \pm 3.0 * * *$ & $247.39 \pm 3.60$ & $268.9 \pm 2.8 * * *$ & $256.08 \pm 3.0 \mathrm{~b}$ & $266.5 \pm 3.8 * * *$ \\
\hline
\end{tabular}

Note: Differences between the weight gain of male and female birds of the same group are noted with *:

$*$ - $\mathrm{P}<0.05 ; * *$ - $\mathrm{P}<0.01$, and $* * *$ - $\mathrm{P}<0.001$.

Differences between values within the same sex, marked with different letters, are proved in:

a-b - P<0.05; f-g - $\mathrm{P}<0.01$, and c-d-e - $\mathrm{P}<0.001$.

Examining the daily change in feed consumption, we found that the most dynamic changes were in the first 7 days of quail life, when weight gain increased between 2.5 and 2.8 times. During this period, the consumption of food became greater most intensively between the 2 nd and 5th day (2.1-2.3 times). The high intensity of increase in feed consumption was maintained in the second week of bird life (Table 5). With age, the growth rate of feed consumption gradually decreased. Nevertheless, by the age of 3 weeks, the average daily consumption in all three groups increased almost linearly, with the mean values in each subsequent weekly period being significantly higher than in the previous one $(\mathrm{P}<0.001)$. During the period between 2228 days, the growth rates of the average daily feed consumption in all three groups decreased significantly, and the effect was most pronounced in the second experimental group. The difference between group II and the other two groups was statistically significant $(\mathrm{P}<0.001)$. However, an explanation for this difference is difficult to be given. In the control and I experimental groups, the growth in feed consumption compared to the previous period was between 10 and $12 \%$, which is a statistically significant difference $(\mathrm{P}<0.001)$. During the period between the 29th and 35th day in the birds of experimental group II there was a more significant increase in feed consumption compared to the other two groups $(\mathrm{P}<0.001)$, which to some extent compensates for the lag from the previous period. During the fifth week, the average daily consumption of feed in all groups stabilized at a level between 31 and $32 \mathrm{~g}$ per day for males and 33 
and $36 \mathrm{~g}$ per day for females. These data correspond to the results published by other authors for quails with similar live weight (14). The efficiency of absorption of nutrients from feed logically decreases with the age of quails. Between the first and second week of the experiment, the conversion of feed deteriorated between 30 and $33 \%$, and the following week between 37 and $49.7 \%$, respectively. Looking at the results obtained by weekly periods, it is difficult to establish the influence of the replacement of $5 \%$ and $10 \%$ of wheat in the combined feed for fattened quails with extruded bakery waste on the analyzed trait. When summarizing the results of feed consumption and the realized growth up to the age of 3 weeks, it was found that during this period the experimental groups absorb nutrients from feed slightly less efficiently, respectively by 1.2 and $3.4 \%$ compared to birds from the control group
(2.181 in the controls versus 2.208 and 2.256 in I and II experimental groups). This tendency continues in the next period (22-28 days), as the difference increases (respectively 6.2 and $4.2 \%$ compared to I and II experimental groups). The influence of the female sex is stronger, in which the difference between the groups is about $8 \%$ (3.853 in the control versus 4.164 in the first experimental group and 3.882 in the second experimental group). Between 29-35 days, the conversion of feed significantly deteriorated, as the male sex had a much greater influence on this result. During this period, the difference in feed conversion between male and female quails reached $27 \%$ (6.79-9.37 in males versus 5.35-6.19 in females). Komarchev (2016) pointed out similar high values for the period $29-42$ days $(7.2-8.9 \mathrm{~kg} / \mathrm{kg}$ growth) in male quails (18).

Table 5. Average daily consumption $(g)$ and average weekly feed conversion ( $g / g$ weight gain)

\begin{tabular}{lcccccc}
\hline $\begin{array}{l}\text { Age, } \\
\text { days }\end{array}$ & Control group & Consumption & II group & \multicolumn{3}{c}{ Feed conversion ratio } \\
& & & & Control & I group & II group \\
\hline $1-7$ & $7.90 \pm 1.34$ & $8.23 \pm 1.35$ & $8.05 \pm 1.27$ & 1.533 & 1.511 & 1.495 \\
$8-14$ & $18.23 \pm 1.37$ & $18.41 \pm 1.45$ & $8.15 \pm 1.27$ & 1.995 & 2.008 & 1.977 \\
$15-21$ & $26.84 \pm 0.57$ & $27.21 \pm 0.60$ & $28.03 \pm 0.62$ & 2.733 & 2.786 & 2.959 \\
$22-28$ & $30.84 \pm 0.37 \mathrm{c}$ & $31.03 \pm 0.23 \mathrm{c}$ & $28.95 \pm 0.36 \mathrm{~d}$ & 3.878 & 4.117 & 4.042 \\
$29-35$ & $33.48 \pm 1.035$ & $32.96 \pm 1.143$ & $32.45 \pm 0.564$ & 6.835 & 6.970 & 6.228 \\
\hline
\end{tabular}

Note: Differences between groups within the same age, marked with different letters, were statistically proven in: $\mathrm{a}-\mathrm{b}-\mathrm{P}<0.05$; f-g $-\mathrm{P}<0.01$, and c-d-e - $\mathrm{P}<0.001$.

Summarizing the results of the experiment (Table 6) we can conclude that for the normal growth of one bird of the WG line up to 35 days of age requires between 794 and $808 \mathrm{~g}$ of feed for males and between 819 and $845 \mathrm{~g}$ for females. During this period, each bird receives with feed 9.24-9.83 MJ of metabolisable energy and 160.1-169.5 $\mathrm{g}$ of crude protein, of which the amino acids critical for the animal organism are
8.37-8.84 $\mathrm{g}$ of lysine and 6.36-6.73 $\mathrm{g}$ methionine + cystine.

For the entire period of the experiment, the female assimilated between 1.2 and $6.1 \%$ more efficiently the nutrients from the feed and formed on average about $8.4 \%$ higher growth. As a result, the value of $1 \mathrm{~kg}$ weight gain is in the range of 1.06-1.08 euros for male quails and 1.01-1.05 euros for females.

Table 6. Productive characteristics of quails from the WG line for the period 1-35 days

\begin{tabular}{|c|c|c|c|c|c|c|}
\hline & \multicolumn{2}{|c|}{ Control group } & \multicolumn{2}{|c|}{ I group } & \multicolumn{2}{|c|}{ II group } \\
\hline & $0^{\pi}$ & q & $0^{\pi}$ & 우 & 0 & q \\
\hline Consumed feed, g/quail & 795.75 & 832.34 & 793.90 & 844.97 & 808.20 & 819.50 \\
\hline Consumed ME, MJ/quail & 9.292 & 9.754 & 9.284 & 9.829 & 9.236 & 9.529 \\
\hline Consumed CP, g/quail & 160.796 & 167.820 & 160.896 & 169.540 & 160.117 & 164.680 \\
\hline Consumed Lysine, g/quail & 8.389 & 8.740 & 8.396 & 8.838 & 8.371 & 8.603 \\
\hline Consumed Cys+met, g/quail & 6.384 & 6.670 & 6.383 & 6.732 & 6.357 & 6.542 \\
\hline Value of feed consumed, EUR/quail & 0.266 & 0.278 & 0.265 & 0.278 & 0.261 & 0.269 \\
\hline FCR & 3.249 & 3.050 & 3.224 & 3.187 & 3.249 & 3.100 \\
\hline EBI & 21.25 & 25.49 & 21.64 & 23.79 & 21.94 & 23.93 \\
\hline EPEF & 22.14 & 26.45 & 22.48 & 24.69 & 22.79 & 24.87 \\
\hline Value per $1 \mathrm{~kg}$ weight gain, EUR & 1.077 & 1.01 & 1.061 & 1.045 & 1.059 & 1.01 \\
\hline Difference, $\%$ & 100 & 100 & -1.49 & +3.47 & -1.67 & 0 \\
\hline
\end{tabular}




\section{CONCLUSION}

Summarizing the results obtained, we can confidently say that the replacement of 5 or $10 \%$ of wheat in the feed mixture with extruded bakery waste, in addition to reducing the value of compound feed by an average of 0.85 and $1.7 \%$, does not adversely affect growth and the productivity of the quails from the WG line, and in the case of the economically most important sign - a value of $1 \mathrm{~kg}$ live weight gain, the difference compared to the control is less than $1 \%$.

\section{RECOMMENDATIONS}

When fattening quails in small farms; up to $10 \%$ of the wheat in the feed mixtures can be successfully replaced by extruded waste from the bakery industry without affecting the productivity of the birds and the economic results of the farm.

\section{REFERENCES}

1. FAO, Agribusiness Handbook: Poultry meat and Eggs. Food and Agriculture Organization of the United Nations, Investment Centre Division, Rome, 2010.

2. OECD/FAO, OECD-FAO agricultural outlook 2016-2025. Organization for Economic Co-operation Development/Food and Agriculture Organization of the United Nations, OECD Publishing, Paris, 2016.

3. FAO, Towards the Future we Want: End Hunger and Make the Transition to Sustainable Agricultural and Food Systems. Food and Agriculture Organization of the United Nations, Rome, 2012.

4. Gustavsson, J., Cederberg, C., Sonesson, U., van Otterdijk R. and Meybeck, A., Global food losses and food waste - Extent, causes and prevention. Food and Agriculture Organization of the United Nations, Rome, 2011.

5. Parfitt, J., Barthel, M. and Macnaughton, S., Food waste within food supply chains: quantification and potential for change to 2050. Philosophical Transactions of the Royal Society B, 365:3065-3081, 2010.

6. Damron, B. L., Waldroup, P. W. and Harms, R. H., Evaluation of dried bakery products used in broiler diets. Poultry Science, 44:1122-1126, 1965.

7. Al-Tulaihan, A. A., Najib, H. and Al-Eid, S.M., The nutritional evaluation of locally produced dried bakery waste (DBW) in the broiler diets. Pakistan Journal of Nutrition, 3(5):294-299, 2004.
8. Yadav, D. S., Shrivastava, M., Singh, J. P. and Mishra, A. K., Effect of replacement of Maize with bakery waste in broiler ration. International Journal of Agricultural Sciences and Veterinary Medicine, 2(1): 28-33, 2014.

9. Kricka, T., Janjecic, Z., Bilandzija, N., Bedekovic, D., Voca, N., Matin, A., Jurusic, V. and Grubor, M., Nutritional usability of thermal treated white and brown bread in broiler feed. Journal of Central European Agriculture, 20(3):788795, 2019.

10.Penkov, D. and Chobanova, S., Metabolizable energy and true digestibility of the protein of extruded of bakery by products (bread wastes) in balanced experiments with poultry. Journal of Central European Agriculture, 21(3):517521, 2020.

11.Marcu, A., Vacaru-Opriş, I., Dumitrescu, G., Ciochină, L. P., Marcu, A., Nicula, M., Peț, I., Dronca, D., Kelciov, B. and Mariş, C., The influence of genetics on economic efficiency of broiler chickens growth. Animal Science and Biotechnologies, 46(2): 339-346, 2013.

12.Naumova, V., V. and Donets, V., N., Myasnaya produktivnosty perepelov porody Faraon v raznye sroki vyrashtivania. Vestnik of Ulyanovsk state agricultural academy, 93-97, 2013. (In Russian)

13. Afanasyev, G. D., Popova, L. A. and Saidu, S. Sh., Myasnaya produktivnosty perepelov raznogo proishozhdenia. Izvestiya of Timiryazev Agricultural Academy, 3:94101, 2015. (In Russian)

14.Golubev, M. I. and Golubeva, T. A., Effektivnosty ispolyzovania suhoy pivnoy drobiny i fermentno-probioticheskoy dobavki v kombikormah pri vyrashtivanii perepelov. Zhivotnovodstvo $i$ veterinarnaya meditsina, 1(16):9-13, 2015. (In Russian)

15.Afanasyev, G. D., Popova, L. A. and Erigina, P. A., Myasnaya produktivnosty perepelov broylernogo tipa na raznyh stadiyah ontogeneza. Ptitsa $i$ ptitseprodukty, 3:50-52, 2013. (In Russian)

16.Genchev, A. and Lukanov, H., Harakteristiki rosta i myasnaya produktivnosty perepelov tyazheloy myasnoy linii WG. Materialy mezhdunarodnoy nauchno-prakticheskoy konferentsii „Sovremennye problemmy v zhivotnovodstve: sostoyanie, reshenia, 
LUKANOV H., et al.

perspektivy“,17-18 oktyabrya, Krasnodar, 34-41, 2019. (In Russian)

17.Genchev, A., Vliyanie na vazrastta na klane na mazhkite padpadatsi varhu proizvodstvoto, kachestvoto i sastava na mesoto. Ptitsevadstvo, XIX(4):26-28, 2010. (In Bulgarian)
18.Komarchev, A. S., Produktivnye i vosproizvoditelynye kachestva perepelov pri ispolyzovanii karotinsoderzhashtih preparatov rastitelynogo proishozhdenia. Autoreferat of Ph.D. Thesis, Moscow, Moscow Timiryazev Agricultural Academy, 2016. (In Russian) 